\title{
List Price Collusion
}

\section{Willem H. Boshoff ${ }^{1}$. Johannes Paha ${ }^{1,2}$ (D)}

Received: 29 November 2019 / Revised: 16 March 2021 / Accepted: 17 March 2021 /

Published online: 20 April 2021

(C) The Author(s) 2021

\begin{abstract}
Firms sometimes collude by agreeing on increases in list prices. Yet, the efficacy of such list price collusion is subject to discussion as colluding firms might, in principle, deviate secretly from the elevated prices by granting their customers discounts. This article reviews cases of list price collusion in the USA and Europe, and it presents a theory of harm suggesting that a combination of anchoring, orientation on reference points, and loss aversion may render list price collusion effective in raising transaction prices-even if firms set transaction prices in a non-coordinated fashion.
\end{abstract}

Keywords List price · Collusion · Discount · Cartel · Antitrust · Anchoring · Reference prices

\section{Introduction}

Many firms set prices using a two-stage process: firms first set list prices and then negotiate discounts with (some) buyers in a subsequent stage. Two-stage price setting may render collusion more difficult: for example, the efficacy of colluding on list prices is not evident if the conspirators offer non-coordinated discounts off the list price. This article investigates the conditions under which agreements on list prices can result in higher transaction prices for customers not purchasing at the list price, even if there are no additional agreements on limiting discounts.

A prominent recent example of list price collusion relates to a cartel among six producers of trucks in the EU, who had exchanged information about the gross list price of trucks, informed each other of their planned gross price increases, and agreed upon harmonizing

Johannes Paha

johannes.paha@wirtschaft.uni-giessen.de

Willem H. Boshoff

wimpie2@sun.ac.za

1 Centre for Competition Law and Economics, Department of Economics, Stellenbosch University, Private Bag X1, Matieland, 7602 Stellenbosch, South Africa

2 Department of Economics and Business, Justus-Liebig-University Giessen, Giessen, Germany 
the list prices over the period 1997 to $2011 .{ }^{1}$ In 2016/2017, the European Commission imposed its hitherto largest fine, i.e., 3.8 bn EUR, on the cartel. In the USA, list price collusion received attention as early as the 1970s, with Hay and Kelly (1974) presenting a range of examples, suggesting that list price collusion was a prevalent phenomenon at the time of their study.

Our article adds to the case study literature on collusion (for example, Grout and Sonderegger 2005; Harrington 2006; Herold and Paha 2018) by presenting evidence of list price collusion. We review economic features of cases decided by competition authorities and courts both in Europe and the USA to emphasize the relevance of list price collusion and to highlight that this practice deserves greater attention in the economics literature. ${ }^{2}$ To characterize agreements on list prices, we distinguish between full collusion, which involves coordination across both stages of price formation (i.e., the explicit fixing of both list prices and discounts), and pure list price collusion, where the firms only agree on list prices (i.e., the coordination is limited to the first stage of pricing).

Agreements on list prices pose a challenge to assessing their economic effects. In both U.S. and European cases, the conspirators have defended their conduct arguing that a conspiracy on list prices, which does not involve agreements on a maximum admissible level of rebates, needs not be effective because any list price increase would have been offset by higher rebates. For example, in the context of the European thread cartel, where the firms had conspired on list prices but also on maximum admissible rebates, one company contended that "list prices have more of a political importance than a competitive one." Another firm held that "the list price increase did not mean that the actual net prices achieved in the relevant market also rose" and that "[c]ustomers are almost never charged the list prices." 3

These challenges matter for practice. Though price fixing is considered anticompetitive by object in many jurisdictions, the circumstances under which agreements on list prices influence the market is important to competition practice, for example, in the context of follow-on damages claims. In damages cases, buyers must demonstrate a causal link between the infringement by producers and the associated harm to buyers. The claimants of damages often find it easier to sue if they can already build on a theory of harm established by a competition authority. Yet, in both the trucks and thread cartel cases, the European Commission remained vague when it came to presenting a theory of harm. ${ }^{4}$

In the trucks case, it argued that the "exchanges, at least, put the [firms] in a position to take account of the information exchanged for their internal planning process and the planning of future gross price increases for the coming calendar year.

\footnotetext{
1 Case AT.39824 — Trucks, Comm'n Decision, C(2016) 4673 final (19 July 2016), at 51, ec.europa.eu/ competition/antitrust/cases/dec_docs/39,824/39824_6567_14.pdf.

${ }^{2}$ A joint analysis of cases from two jurisdictions, Europe and USA, would potentially be difficult if we assessed the legal aspects of the decisions. Since we focus on the economic aspects of the cases, the additional information gained from analyzing cases from two jurisdictions, instead of just one, arguably outweighs any concerns related to differences in legal traditions.

3 Case COMP/383,337/E1/PO - Thread, Comm'n Decision, C(2005)3452 (14 September 2005), at paras. 159-160, http://ec.europa.eu/competition/antitrust/cases/dec_docs/38337/38337_252_1.pdf.

4 American courts have not been much clearer when it comes to formulating a theory of harm. For example, in Re Polypropylene Carpet Antitrust Litigation, the court had relied on a somewhat unsatisfying approach brought forward from Industrial Diamonds: list prices must have a material effect on transaction prices, as firms would not spend time updating and circulating these in the absence of such material effect. In Re Polypropylene Carpet Antitrust Litigation, 996 F. Supp. 18 (N.D. Ga. 1997).
} 
Furthermore, the information may have influenced the price positioning of some of the [firms"] new products." Similarly, by "exchanging EEA-wide applicable gross price lists, [the firms would have] been in a better position to understand from the price increase information [...] each other's European price strategy, than they would have been solely on the basis of the market intelligence at their disposal." The European Commission concluded that by "exchanging current gross prices and gross price lists, combined with other information gathered through market intelligence, the [firms] were better able to calculate their competitors' approximate current net prices". 6

Similarly, in the industrial thread case, the European Commission asserted vaguely that "increasing list prices automatically had an influence on the level of the actual prices. Even if there was no general fixed amount of rebates, the list prices had a target function and served as a starting point for discussion, as well as an indicator from which a percentage discount could be deducted. Consequently, they necessarily had at least a potential and even a likely influence on actual prices.",

The article does not provide new regression results or a formal model. Its purpose is to contextualize the practice of list price collusion by providing a structured summary of the circumstances and cases that support various theories of harm related to list price agreements. We also place the topic in the context of the related literature in empirical, experimental, and theoretical economics (e.g., Harrington 2011), as well as marketing, and behavioral sciences. The information gleaned from the cases and the literature suggests that list price collusion may be effective, especially in the presence of behavioral effects and asymmetric information. The article may therefore also be informative to researchers in the emerging field of behavioral industrial organization (see Grubb and Tremblay 2015 as well as HeidhuesKöszegi 2018 for an overview) about market conduct that is worthwhile being studied in greater detail.

The article identifies key gaps in the literature to assist in the development of improved models of list price collusion as are currently being devised, for example, by Harrington (2020) or Paha (2020a, b). A similar methodological approach as ours, which relies on putting theory in the context of evidence, was taken, for example, by Baker and Salop (2015) in their study of the relationship between antitrust and inequality. By focusing on behavioral effects, our analysis serves the function outlined by Reeves and Stucke (2011), helping to explain "how actual, real world evidence that contradicts (or is unexplainable under) a neoclassical economic theory may nevertheless be insightful in understanding whether conduct is pro- or anticompetitive."

The article is structured as follows. Part 2 presents cases that document the dispute whether list price collusion can raise transaction prices at all if it does not involve additional agreements on eliminating discounts. Part 3 introduces evidence of list price collusion that involved additional agreements on eliminating discounts. The main insights are presented in Part 4 where we study the conditions under which list price collusion can result in higher transaction prices for customers not purchasing at the list price, even if there are no additional agreements on limiting discounts. We show that higher list prices lead to higher transaction prices, by serving as starting points for the negotiations between sellers and buyers. Part 5 concludes.

\footnotetext{
${ }^{5}$ Case AT.39824 - Trucks, supra note 1, at 58.

${ }^{6}$ Case AT.39824 - Trucks, supra note 1, at 47.

7 Case COMP/383,337/E1/PO - Thread, supra note 3, at 165.
} 


\section{The Disputable Effects of List Price Collusion}

We start by considering three examples of U.S. list price collusion cases to document the dispute whether list price collusion can raise transaction prices if it does not involve additional agreements on eliminating discounts. ${ }^{8}$ These three cases elucidate this dispute, with defendants and the courts forwarding opposing views of the effects of list price collusion, along the following lines:

1. The firms typically defended their conduct by arguing that sales were made at prices below the list price, so that list price collusion could not have been effective.

2. The courts found that list price collusion would harm at least those customers who do not shop around for the best price, that is, who buy at the list price.

3. More importantly, the courts found that list price collusion would also harm so-called bargaining customers, as list prices would serve as a starting point for negotiations, thereby resulting in higher transaction prices. We return to this line of argument in Part 4.

One list price case drawing the distinction between different types of buyers is the class action suit concerning High Fructose Corn Syrup (HFCS). ${ }^{9}$ About $50 \%$ of HFCS sales were made with Coca-Cola and Pepsi-Cola, whereas the remaining customers were relatively small. ${ }^{10}$ The conspiracy, which was established in 1988 among the five main producers of HFCS, involved inter alia fixing the price of the lower quality grade of HFCS at a level of $90 \%$ of the price of the higher grade. Furthermore, the producers agreed on raising the list price of the high-quality HFCS (295 F.3d 651: para. 3).

The firms defended their conduct by arguing that the majority of HFCS sales were made at prices below the list price, so that a conspiracy aimed at raising the list prices could not have been effective. The court did not accept this argument, noting that "sellers would not bother to fix list prices if they thought there would be no effect on transaction prices. Many sellers are blessed with customers who are 'sleepers', that is, customers who don't shop around for the best buy; and even for those who do bargain for a lower price, the list price is usually the starting point for the bargaining and the higher it is (within reason) the higher the ultimately bargained price is likely to be" (295 F.3d 651: para. 8).

U.S. courts struck a similar tone in the 1984 Fisher Brothers ${ }^{11}$ case concerning the fixing of prices for copper water plumbing tubes by 9 firms in the period 1975-1982. Copper water plumbing tubes are produced in different categories appearing on price lists that were allegedly fixed by the conspirators. However, one of the defendants argued "that its pricing system is individualized for each transaction, that the actual price for any order is the result of various discounts applied to a standard 'price sheet' price, and that the amount

\footnotetext{
${ }^{8}$ We found case evidence by searching LexisNexis for U.S. antitrust cases where the keyword "list price" showed up prominently. The same procedure was applied to the decisions published on the European Commission's website, where we focused especially on cartels whose formation had previously been studied by Herold and Paha (2018). Therefore, the presented cases constitute anecdotal evidence and should not be interpreted statistically in the sense of certain practices occurring more frequently than others.

${ }^{9}$ United States Court of Appeals, Seventh Circuit. IN RE: HIGH FRUCTOSE CORN SYRUP ANTITRUST LITIGATION. Appeal of A \& W Bottling, Inc., et al. No. 01-3565. Decided: June 18, 2002.

10295 F.3d 651: para. 2.

11 Fisher Brothers, 102 F.R.D. 570, 578 (E.D.Pa.1984).
} 
of discount "varies on a day to day (sometimes hour to hour) basis, depending on numerous factors including [...] changes in the basic cost [of raw materials], meeting a competitor's price [...]" and how much a buyer wants to purchase. The court recognized that similar arguments have been made in other cases and proposed that in a case where "base prices are inflated by a conspiratorial agreement to keep them at a level higher than they would have been without the conspiracy, all purchasers are affected by the price artificially maintained even if the discounts from those base prices vary from purchaser to purchaser and from day to day, depending on a number of other factors. [...] So long as the conspiratorial conduct affects the price sheets commonly used as a starting point, it affects the price ultimately charged to a greater or lesser degree and the fact of impact, if not the amount, is capable of proof on a class basis."

A third U.S. case, which highlights the importance of different customer groups and customer-specific discounts in determining collusive effects, is that of the Glassine and Greaseproof Paper Antitrust Litigation. ${ }^{12}$ This concerned a price-fixing conspiracy from 1973 to 1976 among U.S. producers of glassine and greaseproof paper. The product was sold both to small buyers, who purchased small volumes of standardized products at list prices, and large buyers, who purchased larger volumes of non-standardized products at negotiated prices. The defendants in this private-damages case argued that list price collusion could have had an impact only on those customers paying list prices. The plaintiffs alleged that the conspiracy affected "the prices paid by both types of purchasers, and their interests would be congruent." The court accepted the latter position, noting that the impact on purchasers who negotiated individualized prices could "be shown by a proof that the 'base price' used as a starting point for negotiation was inflated by the artificial conditions caused by the alleged conspiracy."

The findings of the court and the position of the defendants in each of the three cases focus on the second stage of pricing - the discounting or bargaining stage. The defendants in these cases argued that sales were made at prices below the list price and that discounts were determined competitively. Put differently, their line of argument is based on the notion that only those customers who purchased the good at the list price could have been harmed by list price collusion. If one follows this argument, customers buying the good at the discounted price could only be overcharged if the list price collusion cases involved additional agreements on eliminating discounts.

\section{List Price Collusion with Coordination on Discounts}

The literature provides at least some support for the notion that list price collusion can only be effective if it involves additional agreements on eliminating discounts. In their seminal paper on list price collusion, Gill and Thanassoulis (2016) suggest that collusive agreements may be particularly stable, if firms distinguish between list prices and discounts. Their model, along with Harrington (2011), supports a conclusion that successful list price collusion requires, concomitantly, coordination on discounts.

Several cases involve arguments consistent with this view and Part 3.1 suggests selected cases of list price collusion where the firms had indeed agreed explicitly on discounts. Part 3.2, however, considers cases where firms colluding on list prices did not coordinate on discounts, but merely used strategies to discourage salespeople from granting discounts. These cases are therefore closer to pure list price collusion. As argued in Part 3.3 such

${ }^{12}$ In Re Glassine and Greaseproof Paper Antitrust Litigation., 88 F.R.D. 302, 306 (E.D.Pa.1980). 
cases are particularly useful in highlighting that practices aimed at influencing (i.e., discouraging) discounts are critical to the effectiveness of pure list price collusion. The question is whether discounting behavior can still be influenced in the case of pure list price collusion, where such practices are absent. Courts have suggested-as one potential culprit-that list prices can serve as a starting point for negotiations, ultimately resulting in higher transaction prices. Therefore, Part 3.3 ends with the research question: under which conditions can list price collusion result in higher transaction prices for customers not purchasing at the list price, even if there are no additional agreements on limiting discounts?

\subsection{Explicit Coordination on Discounts}

Several collusion cases in the EU and USA involved list price collusion together with explicit coordination on discounts. Full list price collusion could be observed among senior executives in the citric acid industry between 1991 and $1995 .{ }^{13}$ Citric acid is mainly sold to industrial customers, and it is used as an input for producing food and beverages, household detergents and cleansers, or pharmaceuticals and cosmetics. Five companies, whose joint market share in the EEA was $60-70 \%$, were found guilty by the European Commission of colluding on the list prices of citric acid. ${ }^{14}$

Besides agreeing on list prices, the cartel also entailed sales quotas, floor prices, an agreement on avoiding discounts for all but the five largest buyers of citric acid internationally, and the exchange of information about customers. ${ }^{15}$ Concerning the five largest customers, the cartel agreed that discounts might be granted, but capped at a maximum of $3 \%$ off the list price. ${ }^{16}$ Hence, with the exception of the largest buyers, the agreement to avoid discounts implied that final transaction prices were meant to equal the list price.

The European cartel in the market for industrial thread, which was already mentioned in the introduction, constitutes another example of full collusion. Seven firms were participating in this conspiracy, which lasted from 1990 until 2001. The suppliers of industrial thread discussed list prices with an objective of increasing them or maintaining them at a high level. ${ }^{17}$ Because most customers negotiated rebates off the list prices, the participants agreed on list prices and maximum rebates for closing the gap between the list prices and the actual net prices. The net prices, however, were not exchanged among the participants directly. ${ }^{18}$ Discounts "were discussed and agreed during the meetings [... with an objective of] reducing rebates and bonus arrangements. [...] Special prices to customers [...] were also discussed during meetings". ${ }^{19}$

In addition to the agreements on future price lists, discounts, and special prices, there was a general agreement between the participants in the cartel not to undercut the incumbent supplier's price with a view to allocating customers. To apply this agreement, participants in the cartel would contact each other to exchange information and agree on the prices to offer to their customers. ${ }^{20}$

${ }^{13}$ Case COMP/E-1/36 604 - Citric Acid, Comm'n Decision, 2002 O.J. (L 239) 18, at 70.

${ }^{14}$ Case COMP/E-1/36 604 - Citric Acid, supra note 13, at 8-14, 45, 51.

${ }^{15}$ Case COMP/E-1/36 604 - Citric Acid, supra note 13, at 2, 81-84.

${ }^{16}$ Case COMP/E-1/36 604 - Citric Acid, supra note 13, at 83.

${ }^{17}$ Case COMP/383,337/E1/PO - Thread, supra note 3, at 87.

${ }^{18}$ Case COMP/383,337/E1/PO - Thread, supra note 3, at 97, 99, 109.

${ }^{19}$ Case COMP/383,337/E1/PO - Thread, supra note 3, at 165.

${ }^{20}$ Case COMP/383,337/E1/PO - Thread, supra note 3, at 124. 
The U.S. turbine generators case provides another example of firms controlling discounting behavior. In 1962, General Electric and Westinghouse were convicted of illegally fixing the selling prices of turbine generators in the USA. Turbine generators are used in the generation of electricity and the typical buyers are utility companies. In 1963, both General Electric and Westinghouse changed their pricing strategies. Up to that point, each company had published a price book, which determined list prices based on which discounts were determined and/or negotiated. Subsequently, General Electric published a simplified price book as well as a constant multiplier (which could be periodically updated), which could be used by customers (and of course competitors) to determine a final price. Importantly, General Electric also announced a policy of no discounts, together with a most-favored-customer policy that would see recent customers compensated in the event of a subsequent customer receiving a discount. ${ }^{21}$ In 1964, Westinghouse followed General Electric in publishing a similar price book and zero-discount policy. The result was identical prices for the two competitors for several years.

\subsection{Augmented Strategies to Manage Discounts}

The cases presented in Part 3.1 demonstrate instances where discounts were controlled centrally. If transaction prices are negotiated by salespeople further down in a firm's hierarchy, effective list price collusion may require augmenting strategies to manage discounts. These include strategies to centralize pricing authority or the introduction of incentives for salespeople to keep discounts small.

One exemplary case, involving the management of salespeople to achieve coordinated list prices, is a 2002 case dealing with a conspiracy among the fine arts auction houses Christie's and Sotheby's, which occurred between 1993 and 2000 in Europe and the USA. The CEOs of the two auction houses had agreed on a non-negotiable common schedule of commissions to be paid by their customers (i.e., vendors and buyers), which is a form of list price collusion. Yet, the European Commission found that the "specialists in the various departments of Christie's and Sotheby's had considerable flexibility to agree special deals and to attract major business. They frequently made special deals or even waived charges. Hence, although both Christie's and Sotheby's had set a rate of vendor's commission of 10\% in most cases and $6 \%$ for the trade, traditionally there was broad scope for bargaining with their customers. In effect, the commissions were up for negotiation and each auction house undercut the other's prices in order to get the business of a major sale." 22

The employees of the auction houses thus complained about the non-negotiability of the commission structure, which they tried to circumvent as they feared they would otherwise lose business to other auction houses. Senior management thus centralized the authority for making pricing decisions by instructing their employees not to make concessions: "To demonstrate that Sotheby's was 'following suit', [officer of Sotheby's] faxed Christie's with a copy of internal instructions given to staff confirming the strict new practice: all commissions are minimum rates and may not be waived or reduced.

\footnotetext{
21 The effect of best-price and most-favored-customer clauses was analyzed, for example by Cooper (1986), Holt and Scheffman (1987), and Schnitzer (1994).

22 Case COMP/E-2/37.784 — Fine Art Auction Houses, Comm'n Decision, COM(2002) 4283 (30 October 2002), at para. 98, ec.europa.eu/competition/antitrust/cases/dec_docs/37,784/37784_8_4.pdf.
} 
The instructions made clear that the new tariffs would be non-negotiable. Pricing authority was thus ultimately centralized in this cartel."23

Similar provisions can be observed in a 1994 case, in which the EC ruled on collusion among 17 firms in the bulk thermoplastic PVC market. Competitors had adopted identical price lists and agreed on giving salespeople specific instructions to aim at these prices, "emphasizing the need for sales offices to show firmness in support of a particular price initiative. This might involve confining sales to regular customers (avoiding 'tourism'), allowing concessions off the new price list only after obtaining head office approval, or even refusing business rather than brake the price." 24

The strategies adopted in the fine art auction house and thermoplastic PVC cases were intended to manage a principal-agent problem inherent to many list price cartels. The literature suggests that the centralization of pricing authority may be an inefficient solution for these cartels, given that sales representatives often have better knowledge about customers and their willingness to pay.

Additionally, Wilken et al. (2010) investigated how companies steer sales representatives during price negotiations without reducing their pricing authority. They show, based on an experiment with students in business administration, that sales representatives start a negotiation with a higher bid if their company provides them with only coarse cost information instead of detailed information regarding the breakdown into direct costs and overhead expenses. Salespeople want to avoid final sales prices from falling below the direct production costs, and the uncertainty about the level of direct production costs induces sales representatives to estimate the value of these costs conservatively and, thus, they set a high starting bid.

\subsection{On the Necessity of Coordination on Discounts}

The practices of coordinating on, or otherwise influencing, discounts did not feature in several of the exemplary cases mentioned in Part 2. In these cases, courts had accepted a theory of harm for pure list price collusion, positing that higher list prices (in the absence of coordination on discounts) have an elevating effect on final prices. For example, in the Flat Glass Antitrust Litigation, the court followed the position in the High Fructose Corn Syrup case discussed earlier, holding that "[the defendant] does not - it cannot - seriously contend that the competitors increased their list prices with no intention of affecting transaction prices". 25

Courts frequently found that list prices would serve as a starting point for negotiations and would in this capacity also result in higher transaction prices. This line of reasoning is reflected in an internal memorandum found at the premises of one participant in the bulk thermoplastic PVC conspiracy, who acknowledged that "these posted [price] levels will not be achieved in a slack market ... but the announcement does have a psychological effect upon the buyer. An analogy is the car purchase where the 'List price' is set at such a level that the purchaser is satisfied when he obtains his 10-15\% discount, he has struck a 'good deal', but the car producer/garage has still an adequate margin. [Consistent with this line of argument, the Commission concluded that customers] were usually faced with a known marker or reference price in the market. While individual customers might receive special conditions or discounts the setting of a particular price

${ }^{23}$ Fine Art Auction Houses, supra note 21, at para. 112.

${ }^{24}$ Case IV/31.865 - PVC, Comm'n Decision, 1994 O.J. (L 239) 14, at 20.

${ }^{25}$ In re Flat Glass Antitrust Litigation, 385 F. 3d 350 (3d Cir. 2004) at 363. 
as the target meant inevitably that the opportunities for negotiation by customers were circumscribed." 26

This highlights the main question of this article: under which conditions can list price collusion result in higher transaction prices for customers not purchasing at the list price even if there are no additional agreements on limiting discounts?

\section{Pure List Price Collusion}

The considerations presented in Part 3 suggest that courts have relied implicitly on behavioral explanations, especially the notion of list prices serving as starting points. Part 4.1 shows that those starting points are not identical to focal points, and it dismisses hypotheses-of some competition practitioners and researchers-that government-imposed price ceilings or endogenously determined list prices facilitate collusion by serving as focal points.

Parts 4.2 and 4.3 present our alternative theory of harm. Part 4.2 shows that list prices can result in higher transaction prices because of an anchoring effect. However, coordinated conduct will only be relevant for firms if they do not already have an incentive to raise list prices unilaterally. List price collusion will only emerge if there is list price competition otherwise, which prevents the firms from exploiting this starting point/anchoring effect. This may be the case if customers have reference-dependent preferences and perceive a disutility if a firm's list price is above some reference point, e.g., the mean of the list prices of all firms as is demonstrated in Part 4.3.

Part 4.4 comments on the fact that most cases of pure list price collusion were observed in business-to-business markets. We show that this does not preclude the existence of behavioral effects.

\subsection{Focal Points}

Some researchers and competition practitioners have suggested that list prices or price ceilings facilitate collusion by serving as focal points: For example, when analyzing the potential coordinated effects of Sony and BMG's joint venture for recorded music, the European Commission observed "a certain parallelism of the five [major music labels'] wholesale average prices [...]. [The] Commission therefore examined whether any price coordination could have been reached in using list prices [...] as focal points" (Eberl 2004).

A focal point theory also featured centrally in Knittel and Stango's (2003) analysis of the U.S. credit card industry of the 1980s. Interest rates (i.e., prices) in this industry were officially regulated by imposing a ceiling on prices. Knittel and Stango (2003) identified the distribution of prices under competition. They then showed that the prices in several regional markets differed from this competitive distribution by being distorted upwards towards the price ceiling. Based on these observations, they hypothesized that price ceilings might have functioned as a focal point for tacit collusion among the firms. ${ }^{27}$

A similar hypothesis might carry over to list prices because price ceilings and list prices share the characteristic of being nonbinding in determining transaction prices. To be more specific about the theory of harm potentially following from these observations, a

26 Case IV/31.865 — PVC, Comm'n Decision, 1994 O.J. (L 239) 14, at 19, 22.

27 Further evidence to support the collusive effects was provided; for example, by Ma (2007) and Lewis (2015). 
focal point theory of collusion may be interpreted in the context of equilibrium selection. Especially in markets with asymmetric information there may be multiple collusive and non-collusive equilibria. Agreeing on list prices may then function as a device helping the firms to coordinate on an equilibrium with higher profits than would have been realized otherwise.

Studies in experimental economics have sought to identify focal point effects of nonbinding price ceilings or price pre-announcements in the laboratory but have not found strong evidence. For example, Engelmann and Normann (2009) conduct an experiment where firms/subjects compete in a market by setting prices. After 30 out of 60 periods, the authors either introduce or remove a price ceiling that can either be high or low. They find that the prices in all treatments are often close to the prices predicted for a competitive Nash equilibrium and there are hardly any attempts to collude in their experiment in general. Therefore, Engelmann and Müller ran a similar experiment that was explicitly "designed to facilitate collusion at a price ceiling, while making collusion in the absence of a price ceiling relatively difficult" (Engelmann and Müller 2011). Despite these efforts they do not find any evidence either that would support the hypothesis of price ceilings having a collusive effect by being considered focal points of firms' coordination efforts.

Harrington et al. (2016) find a similar result. They study the collusive effects of price pre-announcements, which share similarities with list prices because they are public information among the cartel firms, they are set before the market clears, and they may differ from final transaction prices. Harrington et al. (2016) find evidence in support of the hypothesis that firms set higher prices when they can make price pre-announcements, yet only in duopolistic markets. Price announcements are not found to produce supracompetitive prices or greater coordination if there are more than two firms. ${ }^{28}$

We conjecture that similar results carry over to the topic of list price collusion. There is thus little reason to believe that list price collusion is effective just because list prices serve as focal points for firms' coordination efforts. Indeed, in its investigation of Sony and BMG's joint venture for recorded music, the European Commission found no conclusive evidence that the major music labels had indeed aligned their discounts despite the parallelism of list prices.

\subsection{Anchoring and Adjustment}

We now provide support to the hypothesis advanced by courts, namely that by serving as starting points for negotiations, higher list prices result in higher transaction prices. We propose that this may be the case because of a behavioral anchoring effect.

Anchoring strategies were initially described by Tversky and Kahneman (1974) who suggest that "people make estimates by starting from an initial value that is adjusted to yield the final answer [... and that] adjustments are typically insufficient. That is, different starting points yield different estimates, which are biased toward the initial values." Kahneman (1992) explains that anchoring can even influence the normality of a possible outcome if the stimulus or message is clearly designated as irrelevant and uninformative. For example, a list price set by a firm might be uninformative if a customer decides about the purchase of a product only with recourse to the transaction price, which is the difference between the list price and the discount. Then, all combinations of the list price and discount that yield the same transaction price should be equivalent,

\footnotetext{
28 The finding that collusion can hardly be observed in settings with more than two firms is fairly robust and has been shown by a variety of other experiments. For an overview, see Haan et al. (2009).
} 
and the list price alone would be uninformative. However, the list price may still have a behavioral effect on transaction prices by serving as an anchor.

Support for this hypothesis was provided by an experiment conducted by Northcraft and Neale (1987). They invited students as well as professional real estate agents to examine a piece of property that was on sale in Tucson, Arizona. And they asked the participants to complete a short questionnaire concerned with estimating the value of the property. Each subject received a packet with information about the property including its listing price as well as listing information for other property in the immediate neighborhood. While the actual listing price was $\$ 74,900$ the participants were grouped in four treatments and provided with listing prices of $\$ 71,900, \$ 77,900$, i.e., $\pm 4 \%$ of the actual listing price, $\$ 65,900$, or $\$ 83,900$, i.e., $\pm 12 \%$ of the actual listing price.

Northcraft and Neale found that the participants' estimates of the appraised value of the property varied significantly with the listing price. For example, the students who had been shown a listing price of $\$ 65,900$ indicated an average appraisal value of $\$ 63,571$ whereas the real estate agents stated $\$ 67,811$. The students who had been shown a listing price of $\$ 83,900$ indicated an average appraisal value of $\$ 72,196$ whereas the real estate agents stated $\$ 75,190$. While the real estate agents recognized that the property was undervalued at a listing price of $\$ 65,900$, their estimated appraisal values were still influenced by the stated listing price. This is although only $15 \%$ of the amateur and $10 \%$ of the expert subjects stated they had started their valuation at a reference value that they adjusted for observable characteristics. $67.4 \%$ of the amateur and $77.5 \%$ of the expert participants stated they had mostly relied on comparisons with the market values of neighborhood housing. Hence, although most of the participants believed they had applied an objective valuation strategy, the findings indicate that they, in fact, had been affected by the stated listing price, and this was the case also for the professional real estate agents and although they should have been able to recognize the two extreme departures from the actual listing price. Repeating the experiment with another piece of property yielded similar results.

Anchoring effects can be observed not only under experimental but also under realworld conditions, because past selling prices of, or presale estimates for, a piece of art have also been found to induce an anchoring effect. Beggs and Graddy (2009) show empirically, for a dataset on Impressionist/Modern Art auctions and a dataset on Contemporary Art auctions, that paintings, which were sold at higher prices in the past, are typically also sold at higher prices in the present. This result holds even after controlling for observable characteristics. In addition to causing anchoring by the buyers, past prices are also found to establish an anchoring effect on art experts' presale valuations.

Anchoring effects are also observed in the negotiation literature. Ritov (1996) found, among others, that the initial offer in bilateral negotiations under experimental conditions serves as an anchor. In other words, if the buyer started the negotiation with a low offer, the final transaction price was lower in comparison to a situation where the seller started the negotiation with a high offer. This result was generated by an experiment where 184 Management and Industrial Engineering students were assigned the roles of sellers or buyers and negotiated over the sale of some item. This result of initial bids affecting the outcome of a negotiation has also been termed starting point bias (Boyle et al. 1985).

This evidence suggests that list price collusion may be effective because of the anchoring effect: By serving as starting points for negotiations, higher list prices result in higher transaction prices as was already presumed by courts. It resembles the bargaining effect presumed by Harrington and Ye (2019) in a model with asymmetric information about costs: they assumed that buyers bargain less aggressively upon observing a higher list price that they mistake as a signal of a firm producing at high costs. 
The evidence presented, however, suggests that the anchoring effect may sometimes also establish an incentive for firms to set high list prices unilaterally as is observed, for example, by supermarkets who post the actual price alongside a higher recommended price. This raises the question why the firms would want to resort to coordinated conduct for setting high list prices. This question is addressed in Part 4.3.

\subsection{Reference Points and Loss Aversion}

For list price collusion to arise, there must be list price competition absent any agreements or coordinated conduct. We propose that list price competition emerges because final prices are not only affected by anchoring effects but also by customers' orientation on reference points in combination with loss aversion.

The distinction between reference points and anchors was defined by Kahneman: Anchoring refers to "cases in which a stimulus or a message that is clearly designated as irrelevant and uninformative nevertheless increases the normality of a possible outcome." A "reference point [however] separates [a] domain into regions of desirable outcomes (gains) and undesirable ones (losses)" (Kahneman 1992) and firms may want to affect customers' reference points by setting list prices strategically. The concept of reference points is related to Thaler's (1985) concept of mental accounting: If a buyer already entered an expenditure equaling the reference price in her mental account, paying a higher price will be considered a loss, whereas paying a lower price constitutes a gain, and each firm may want its customers to perceive the purchase of its product as a gain.

To understand why customers' orientation on reference points may be a prerequisite for list price competition and-in the end-list price collusion, it will be helpful to define reference prices more closely. In the marketing literature, one distinguishes between internal reference prices, which are in the mind of the buyer and based on actual, fair, or other price concepts, and external reference prices, which are observed stimuli in the physical environment such as list prices, posted prices, or suggested retail prices that stores display alongside sale prices. The boundary between internal and external reference prices is somewhat blurred because, over time, internal reference prices can be updated if new external stimuli emerge such as observed prices or price promotions. ${ }^{29}$

In the following, we are mostly concerned with two types of reference prices. Firstly, a buyer may compare the transaction price actually charged to the posted list price of the same firm. Once a buyer has entered the list price in her mental account, a discount would be considered a gain, and the buyer experiences a higher utility and, thus, willingness to pay, as opposed to being presented the transaction price right away. This effect works in the same direction as the anchoring effect described above, i.e., firms would unilaterally have an incentive to set a higher list price. ${ }^{30}$

\footnotetext{
29 A literature review of research on reference prices was provided by Mazumdar et al. (2005).

In a retail context, reference prices may affect both store choice decisions and brand choice decisions (Mayhew and Winer, 1992).

30 To provide further evidence where reference points and anchoring reinforce each other, Kristensen and Gärling (1997) provide evidence from an experiment with 72 undergraduate students in Sweden who were assigned the roles of buyers and sellers of a condominium. The authors show that the number of a buyer's counteroffers was on average higher when the seller's initial offer was perceived as a loss, i.e., if it was above the buyer's reservation price. Hence, reference point effects may affect the intensity of bargaining. As an additional result in line with the anchoring effects discussed above, Kristensen and Gärling (1997) also find that buyers' first and last counteroffers increased in the size of the sellers' initial offers, which apparently served as anchors.
} 
Secondly, a buyer may compare the posted list price of the firm to a reference price that is a function (e.g., the average or the minimum) of the list prices of several firms. A disutility will be felt by the customer if the list price is perceived as a loss. The customer would thus be less likely to engage in negotiations with the seller. ${ }^{31}$ This causes list price competition and provides a first answer to the main question posed at the beginning of this part, i.e., why the firms would want to resort to coordinated conduct for raising list prices: We suggest that higher list prices contribute to higher transaction prices because of the anchoring effect, whereas orientation on reference points and loss aversion causes list price competition, so that list price collusion may help raising transaction prices.

The concept of price fairness provides another, related reason that prevents firms from raising list prices unilaterally, and that may thus be considered a prerequisite for list price collusion. Price fairness was studied, for example, by Xia et al. (2004). They argue that customers might perceive price discrepancies between two transactions as unfair, which in the context of setting list prices might be taken as an impediment to unilaterally raising list prices beyond a certain point. Under such circumstances, list price collusion may help shifting up the maximum reference price that customers are willing to accept. That such a maximum acceptable reference price exists follows from Kopalle and Lindsey-Mullikin (2003), who provide evidence from an experiment suggesting an inverse u-shaped relationship between customers' expectation of the regular price and the external reference price.

Enhanced loss aversion constitutes a third reason that prevents firms from raising prices unilaterally. Enhanced loss aversion occurs if losses "that are compounded by outrage are [considered] much less acceptable than losses that are caused by misfortune or by legitimate actions of others" (Kahneman 1992). For example, a customer might consider a unilateral increase in the price of one firm as less legitimate than a collective increase. This might potentially cause the buyers to raise their reservation price when observing a collective increase of list prices. For example, Harrington and Ye (2019) assumed that customers would rationalize a collective increase of list prices by attributing it to a common cost shock.

Their additional assumption of customers responding to such a common cost shock by raising their reservation prices and, thus, bargaining less aggressively may potentially be explained with recourse to the concept of enhanced loss aversion: A common cost shock may be perceived by the customers as a misfortune on the sellers' side and thus as a legitimate event that is not going to be punished by outrage. This is in line with Xia et al. (2004) who review literature suggesting that price increases caused by (apparent) input price shocks are considered less unfair than price increases in response to managerially influenced cost increases. Putting these considerations together, orientation on reference points, (enhanced) loss aversion, and the notion of price fairness may all be causes of list price competition that firms may try to avoid by engaging in list price collusion.

\subsection{Business-to-Business Markets}

Future research on list price collusion should also consider one further empirical observation: pure list price collusion seems to be an issue mostly in business-to-business markets. We found only two cases of list price collusion where buyers are final consumers. These are the U.S. conspiracy among dealers of Plymouth cars and the European

\footnotetext{
31 This resembles the inclusion effect in the model of Harrington and Ye (2019), according to which buyers are less likely to consider products whose list price is high.
} 
fine art auction house cartel. ${ }^{32}$ In all other cases, buyers are businesses so that the discounts are not set unilaterally by the sellers but negotiated bilaterally between sellers and buyers.

This is relevant because research on behavioral aspects has mostly concentrated on business-to-consumer (B2C) markets, whereas pure list price collusion seems to be an issue mostly in business-to-business (B2B) markets. This requires demonstrating that behavioral effects can also be observed in the B2B context. Research on this issue is still developing. Based on a metastudy, Monroe et al. (2015) argue that behavioral effects are equally prevalent in B2B markets. Their "results provide strong evidence for the applicability of the reference price concept in B2B markets" (Monroe et al. 2015). They derive the conclusion from research from cognitive psychology, marketing research, and negotiation science that indicate that humans are prone to anchoring and reference point effects both in a B2C and a B2B context. ${ }^{33}$ Reeves and Stucke (2011) provide another literature review suggesting that firms (or, in effect, their employees) are subject to behavioral biases. Further contributions on firms with behavioral biases have recently been published in a special issue of the Review of Industrial Organization (see Tremblay and Xiao (2020) for an introduction). The evidence presented in Part 4.2 provides further support to the hypothesis that professional, experienced buyers are subject to anchoring effects.

\section{Conclusion}

This article asked under which conditions list price collusion results in higher transaction prices for customers not purchasing at the list price even if there are no additional agreements on limiting discounts. Inspired by recent evidence on list price collusion, we have reviewed several competition cases which suggest that agreements on list prices without coordinating on discounts are quite prevalent in the USA and Europe. Even so, few researchers have sought to explore the conditions that would render this practice effective in raising final transaction prices. This article constitutes one step towards filling this gap by not only reviewing recent cases but also placing them into perspective regarding the relevant literature.

Several of the reviewed cases accord with literature in economics according to which list price collusion is mainly effective if at least some of the customers buy the product at the (elevated) list price, if the firms also agree on an admissible level of discounts, or

\footnotetext{
32 In 1960, a case was brought to the U.S. Court of Appeals for the Ninth Circuit where the Plymouth Dealers' Association of Northern California was accused of having conspired to stabilize the retail prices of Plymouth motor cars (279 F.2d 128: paras. 1-2). In particular, the Association had printed and published a price list that was circulated to its members (279 F.2d 128: para. 5). This had caused the list prices to rise above the retail price recommended by the manufacturer. No further agreements on discounts were mentioned. The Plymouth Dealers' Association argued that the increase in list prices was a device for giving larger allowances and trade-ins, so that the actual net retail price would not have been affected by this conduct (279 F.2d 128: para. 7). The court, however, found that the "competition between the Plymouth dealers and the fact that the dealers used the fixed uniform list price in most instances only as a starting point, is of no consequence. It was an agreed starting point; it had been agreed upon between competitors; it was in some instances in the record respected and followed; it had to do with, and had its effect upon, price" (279 F.2d 128: para. 17).

33 Also see Wilken et al. 2010.
} 
if they use additional measures for controlling discounts (such as centralizing pricing authority or incentivizing salespeople to conform with the objectives of the cartel). In other cases, the firms had not taken any documented provisions for controlling discounts. Yet, the courts typically presumed that pure list price collusion would still be effective in raising final transaction prices, often relying on behavioral hypotheses: the courts either viewed list prices serving as starting points or anchors in buyers' negotiations with sellers or hypothesized that list prices might serve as focal points facilitating firms' coordination on a collusive equilibrium at supracompetitive prices.

The experimental economics literature does not provide strong support for the hypothesis of list prices serving as focal points. However, evidence both from the lab and the field indicate that higher transaction prices could result from a behavioral anchoring effect, even though the literature is not clear on why the firms would need to agree on higher list prices in a coordinated fashion. This is because the anchoring effect might provide an incentive for setting high list prices even unilaterally. This unilateral incentive may however vanish if customers are averse to a list price above the list prices of other sellers, which may induce list price competition that the firms possibly try to escape by coordinating on higher list prices.

Our findings support the position of courts that list price collusion may be effective in producing higher prices even if there is no coordination on discounts and if the final prices are bargained bilaterally between sellers and buyers. These findings are relevant, for example, when it comes to presenting a theory of harm in lawsuits where the buyers claim damages for the harm incurred from pure list price collusion. More research will, however, be needed to study list price collusion in a formal-analytic modeling framework. ${ }^{34}$

Acknowledgements We thank Cornel Bekker for his research assistance. We are grateful for further helpful comments that were provided by Kai Hüschelrath (the editor) and three anonymous referees.

Funding Open Access funding enabled and organized by Projekt DEAL.

\section{Declarations}

Ethical Approval No ethical scrutiny for this study was required from any ethics committee, as the study involved an analysis of publicly available research and court decisions. No new data was collected, implying no potential for harm.

Informed Consent The research did not involve any human participants or animals.

Conflict of Interest Johannes Paha advises a claimant for damages in the trucks case. At the time of working on this article, Johannes Paha advised a claimant for damages in the trucks case. There is no conflict of interest because the article only mentions this case but does not make any specific assessment of it. Willem Boshoff has previously advised a client involved in alleged list price collusion (the subject of this paper), but the case was abandoned.

\footnotetext{
${ }^{34}$ In the economics literature, the effects of reference points and loss aversion on market outcomes have been studied, for example, by Heidhues and Köszegi $(2008,2014)$ or Spiegler (2012) in static models focusing on competition rather than collusion. To study list price collusion meaningfully, these static models would have to be made dynamic, the process of reference price formation would have to be spelled out explicitly, and one would have to distinguish between list prices and transaction prices. In making these models dynamic, one might potentially rely on contributions in the marketing literature, such as those made by Greenleaf (1995), or by Kopalle et al. 1996 and in the economics literature, such as by Ahrens et al. (2017).
} 
Open Access This article is licensed under a Creative Commons Attribution 4.0 International License, which permits use, sharing, adaptation, distribution and reproduction in any medium or format, as long as you give appropriate credit to the original author(s) and the source, provide a link to the Creative Commons licence, and indicate if changes were made. The images or other third party material in this article are included in the article's Creative Commons licence, unless indicated otherwise in a credit line to the material. If material is not included in the article's Creative Commons licence and your intended use is not permitted by statutory regulation or exceeds the permitted use, you will need to obtain permission directly from the copyright holder. To view a copy of this licence, visit http://creativecommons.org/licenses/by/4.0/.

\section{References}

Ahrens S, Pirschel I, Snower DJ (2017) A theory of price adjustment under loss aversion. J Econ Manage Strat 134:78-95

Baker JB, Salop SC (2015) Antitrust, competition policy, and inequality. Georgetown Law J 104(1):1-28

Beggs A, Graddy K (2009) Anchoring effects: evidence from art auctions. Am Econ Rev 99(3):1027-1039

Boyle KT, Bishop RC, Welsh MP (1985) Starting point bias in contingent valuation bidding games. Land Econ 61(2):188-194

Cooper TE (1986) Most-favored-customer pricing and tacit collusion. Rand J Econ 17:377-388

Gill D, Thanassoulis J (2016) Competition in posted prices with stochastic discounts. Econ J 126:1528-1570

Eberl P (2004) Following an in-depth investigation the Commission approved the creation of the Sony/BMG music recording joint venture on 19 July 2004. 3 2004. Competition Policy Newsletter, at 7-10. https:// bit.ly/33420f8. Accessed on 20 Nov 2019

Engelmann D, Müller W (2011) Collusion through price ceilings? In search of a focal-point effect. J Econ Behav Organ 79:291-302

Engelmann D, Normann H-T (2009) Price ceilings as focal points? An experimental test. In: Hinloopen J, Normann H-T (eds) Experiments and Competition Policy. Cambridge University Press, Cambridge, pp 61-80

Greenleaf EA (1995) The impact of reference price effects on the profitability of price promotions. Market Sci 14(1):82-104

Grout PA, Sonderegger S (2005) Predicting cartels. OFT Discussion Paper 1773. https://bit.ly/2JWewtg. Accessed on 7 Dec 2020

Grubb MD, Tremblay VJ (2015) Introduction: behavioral industrial organization. Rev Ind Organ 47(3):243-245

Haan MA, Schoonbeek L, Winkel BM (2009) Experimental results on collusion: the role of information and communication. In: Hinloopen J, Normann H-T (eds) Experiments and competition policy. Cambridge University Press, Cambridge, pp 9-33

Harrington JE (2006) How do cartels operate? Found Trends Microecon 2(1):1-105

Harrington JE (2011) Posted pricing as a plus factor. J Competition Law Econ 7(1):1-35

Harrington JE (2020) The anticompetitiveness of sharing prices. Mimeo, 1-31

Harrington JE, Gonzalez RH, Kujal P (2016) The relative efficacy of price announcements and express communication for collusion: Experimental findings. J Econ Behav Organ 128:251-264

Harrington JE, Ye L (2019) Collusion through coordination of announcements. J Ind Econ 67(2):209-241

Hay GA, Kelly D (1974) An empirical survey of price fixing conspiracies. J Law Econ 17(1):13-38

Heidhues P, Köszegi B (2008) Competition and price variation when consumers are loss averse. Am Econ Rev 98(4):1245-1268

Heidhues P, Köszegi B (2014) Regular prices and sales. Theor Econ 9(1):217-251

Heidhues P, Köszegi B (2018) Behavioral industrial organization. In: Bernheim BD, DellaVigna S, Laibson D (eds) Handbook of behavioral economics - foundations and applications 1. Elsevier, Amsterdam, pp 517-612 ((Ch. 6))

Herold D, Paha J (2018) Cartels as defensive devices: evidence from decisions of the European Commission 2001-2010. Rev Law Econ 14(1):1-31

Holt CA, Scheffman DT (1987) Facilitating practices: the effects of advance notice and best-price policies. Rand J Econ 18:187-197

Kahneman D (1992) Reference points, anchors, norms, and mixed feelings. Organ Behav Hum Dec 51:296-312

Knittel CR, Stango V (2003) Price ceilings as focal points for tacit collusion: evidence from credit cards. Am Econ Rev 93:1703-1729 
Kopalle PK, Lindsey-Mullikin J (2003) The impact of external reference price on consumer price expectations. J Retail 79:225-236

Kopalle PK, Rao AG, Assunção J (1996) Asymmetric reference price effects and dynamic pricing policies. Market Sci 15(1):60-85

Kristensen H, Gärling T (1997) The effects of anchor points and reference points on negotiation process and outcome. Organ Behav Hum Dec 71(1):85-94

Lewis MS (2015) Odd prices at retail gasoline stations: focal point pricing and tacit collusion. J Econ Manage Strat 24:664-685

Ma T-C (2007) Import quotas, price ceilings, and pricing behavior in Taiwan's flour industry. Agribusiness 23:1-15

Mayhew GE, Winer RS (1992) An empirical analysis of internal and external reference prices using scanner data. J Consum Res 19(1):62-70

Mazumdar T, Raj SP, Sinha I (2005) Reference price research: review and propositions. J Marketing 69(4):84-102

Monroe KB, Rikala V-M, Somervuori O (2015) Examining the application of behavioral price research in business-to-business markets. Ind Market Manag 47:17-25

Northcraft GB, Neale MA (1987) Experts, amateurs, and real estate: an anchoring-and-adjustment perspective on property pricing decisions. Organ Behav Hum Dec 39:84-97

Paha J (2020a) Competition in list prices. Mimeo, 1-28

Paha J (2020b) Collusion in list prices. Mimeo, 1-23

Ritov I (1996) Anchoring in simulated competitive market negotiation. Organ Behav Hum Dec 67(1):16-25

Reeves AP, Stucke ME (2011) Behavioral antitrust. Indiana Law J 86(4):1527

Schnitzer M (1994) Dynamic duopoly with best-price clauses. Rand J Econ 25:186-196

Spiegler R (2012) Monopoly pricing when consumers are antagonized by unexpected price increases: a "cover version" of the Heidhues-Köszegi-Rabin model. Econ Theor 51(3):695-711

Thaler R (1985) Mental accounting and consumer choice. Market Sci 4(3):199-214

Tremblay VJ, Xiao M (2020) Introduction: firms with behavioral biases. Rev Ind Organ 56(2):199-202

Tversky A, Kahneman D (1974) Judgment under uncertainty: heuristics and biases. Science 185:1124-1131

Wilken R, Cornelißen M, Backhaus K, Schmitz C (2010) Steering sales reps through cost information: an investigation into the black box of cognitive references and negotiation behavior. Int $\mathrm{J}$ Res Market 27(1):69-82

Xia L, Monroe KB, Cox JL (2004) The price is unfair! A conceptual framework of price fairness perceptions. J Marketing 68(4):1-15

Publisher's Note Springer Nature remains neutral with regard to jurisdictional claims in published maps and institutional affiliations. 